\title{
Effect of Biostimulants on Growth and Floral Attributes of Tuberose (Polianthes tuberosa L.). cv. Prajwal
}

\author{
Kahkashan Bano Karim*, Nellipalli Vinod Kumar, B. Raghupati and A.K. Pal \\ Department of Floriculture and Landscaping, Faculty of Horticulture, \\ Bidhan Chandra Krishi Viswavidyalaya Mohanpur, Nadia, 74125, West Bengal, India \\ *Corresponding author
}

\begin{abstract}
A B S T R A C T
An experiment was conducted at Horticultural Research Farm, Mondouri, and Bidhan Chandra Krishi Viswavidyalaya during April 2015 to March 2016 to study the effect of different organic manures on growth and flowering of tuberose (Polianthes tuberosa L.) cv. Prajwal. The experiment was laid out in Randomized Block Design with three replications, with nine treatments. The treatments include vermicompost $(2000 \mathrm{~g} \mathrm{sq} / \mathrm{m})$, neem cake $(400 \mathrm{~g} \mathrm{sq} / \mathrm{m})$ poultry manure $\left(1000 \mathrm{~g} \mathrm{sq} \mathrm{m}^{-1}\right)$ and FYM $(4000 \mathrm{~g} \mathrm{sq} / \mathrm{m})$ were applied individually and all the treatments were repeated with the combination of treatments of seaweed. The observations on vegetative and reproductive growth were recorded. . Among growth parameters, plant height and number of leaves were highest in treatment $\mathrm{T}_{6}$ (Seaweed+Vermicompost @2000g/sq m), leaf length was found maximum in $\mathrm{T}_{8}$ (seaweed+ neem cake@200g/sq m) and maximum leaf breadth was found in $\mathrm{T}_{5}$ (seaweed+poultry manure@ $1000 \mathrm{~g} / \mathrm{sq} \mathrm{m}$ ). All the flower parameters varied significantly among treatments except diameter of spike. Flowering parameters like, spikes length, number of florets, weight of ten florets, length of florets and rachis length were found to be maximum in $\mathrm{T}_{6}$ (Seaweed+Vermicompost @2000g/sq m). Weight of spikes was maximum in $\mathrm{T}_{8}$ (Seaweed+Neem cake @400g/sq m) where, floret diameter was maximum in case of $\mathrm{T}_{4}$ (Neem cake @ $\left.400 \mathrm{~g} / \mathrm{sq} \mathrm{m}\right)$.With respect to quality parameters, vase life was highest in treatment $\mathrm{T}_{8}$ (Seaweed+Neem cake @ $400 \mathrm{~g} / \mathrm{sq} \mathrm{m}$ ) and in treatment $\mathrm{T}_{6}$ (Seaweed+Vermicompost @ 2000g/sq m). And the flower yield was found to be maximum in the treatment $\mathrm{T}_{6}$ (Seaweed+Vermicompost @ 2000g/sq m). The interpretation of the data reveals that sole application of organic manures and in combinations with seaweed significantly affected the quantitative and qualitative characters of tuberose. So it may be concluded that application of seaweed+ Vermicompost @2000g sq m and Seaweed+Neem cake@400g sq m showed significant improvement in vegetative growth, flowering and post harvest attributes through increased availability of nutrients in the soil.
\end{abstract}

\section{Introduction}

Tuberose is botanically known as Polianthes tuberosa $\mathrm{L}$. belongs to the family Agavaceae. It is a bulbous perennial plant. The spikes are used as cut flowers and loose flowers. Tuberose cultivars are mainly three types - single, semi double and double. Single flowered cultivars are more fragrant and extensively used for essential oil extraction as the concrete percent has been observed to be more $(0.08$ to $0.11 \%)$ compared to double. 
The deterioration of soil fertility through use of chemical fertilizers and increasing production cost due to chemical fertilizers brought an urge for organic sources of nutrients as a part of nutrient requirement. Tuberose requires a large quantity of NPK, both in the form of organic and inorganic fertilizers. Nitrogen, phosphorus and potassium have a significant effect on spike production and floret quality. Duration of flower in the field was improved through using organic fertilizer. Poultry manure is an excellent organic fertilizer, as it contains high nitrogen, phosphorus, potassium and other essential nutrients. Vermicompost has been shown to have high levels of total and available nitrogen, phosphorus, potassium, micronutrients, microbial and enzyme activities and growth regulator. Neem cake is an excellent source of organic amendment can replace not only the use of chemical fertilizers but also replace the use of pesticides by suppressing pathogens and insects. In North America, the bio-stimulant coalition defined biostimulants as "substances, including micro-organisms, that are applied to plant, seed, soil or other growing media that may enhance the plant's ability to assimilate applied nutrients, or provide benefits to plant development. The different categories of plant biostimulants that we review are i. microbial inoculants, ii. humic acids, iii. fulvic acids, iv. Protein hydrolysates and amino acids, and v. seaweed extracts. Seaweeds are a diverse assemblage with close to 10,000 species of red, brown and green seaweeds described (Khan et al, 2009). Based on abundance and distribution, brown seaweeds (phaeophyta) are some of the most commonly used for the commercial manufacture of extracts for applications in agriculture and horticulture. These extracts are reported to act as chelators, improving the utilization of mineral nutrients by plants and improving soil structure and aeration, which may stimulate root growth. Sea weed extracts also act as biostimulants, enhancing seed germination and establishment, improving plant growth, yield, flower set and fruit production, increasing resistance to biotic and a biotic stresses, and improving postharvest shelf life.

\section{Materials and Methods}

The field experiment was conducted during April 2015 to March 2016 at Horticultural Research Station, Mondouri, Bidhan Chandra Krishi Viswavidyalaya, Mohanpur, Nadia, West Bengal. The experiment was conducted in randomized block design with three replications. The plot size is $1 \times 1.5 \mathrm{~m}$ with $30 \times 30 \mathrm{~cm}$ spacing. Uniform size of $2.5-3 \mathrm{~cm}$ diameter bulbs of tuberose variety Prajwal are planted in the first week of April 2015. The soil is sandy loamy in texture having ph 6.5-7. The available $\mathrm{N}$ is $0.07 \% \mathrm{P}$ is $28.5 / \mathrm{ha}$ and $\mathrm{k}$ is $78 \mathrm{~kg} / \mathrm{ha}$. The application comprises of organic manures like Farm yard manure @ 4kg/sqm, Vermicompost @ $1.5 \mathrm{~kg} / \mathrm{sqm}$ Neemcake @400/sqm Poultry manure @1 $\mathrm{kg} / \mathrm{sqm}$ are applied as basal dose then seaweed (Kappaphycus spp) at $2.5 \%$ is applied in $2^{\text {nd }}$ week of June and the repeated four times at monthly interval. All the cultural practices were kept uniform for all the treatments and standard practices were adopted. Flowers were harvested in November months at peak season of flowering and data were recorded.

\section{Results and Discussion}

\section{Vegetative parameters}

Significant maximum results were found in the treatment $\mathrm{T}_{6}$ (Seaweed +Vermicompost $2000 \mathrm{~g} / \mathrm{sq} \mathrm{m}$ ) with respect to plant height $(68.92 \mathrm{~cm})$ and the minimum plant height $(54.33 \mathrm{~cm})$ was observed in control $\left(\mathrm{T}_{0}\right)$ followed by $\mathrm{T}_{1}$ (poultry manure $1000 \mathrm{~g} / \mathrm{sq} \mathrm{m}$ ) $(60.44 \mathrm{~cm})$ (Table 1). 
The improvement in plant height in tuberose with the addition of organic manures was also reported by Kabir et al., (2011). The improvement in plant height in banana with the addition of seaweed was also reported by Karthikeyan et al., (2014).

With respect to number of leaves, the treatment $\quad \mathrm{T}_{6} \quad$ (Seaweed+Vermicompost @ 2000g/sq.m) showed the highest number of leaves (62.78) and the minimum number of leaves (36.78) was observed in control $\left(\mathrm{T}_{0}\right)$ followed by $\mathrm{T}_{1}$ (Poultry manure@1000g/sq. m) (48.11).The results were related to the findings of Kabir et al., (2011) in tuberose. Tripathy et al., (2012) reported the more number of leaves with the application of organic manure. This result was also supported by Karthikeyan et al., (2014) in banana.

When the sole application and combinations of organic manures were compared, the combination of $\mathrm{T}_{8}$ (Seaweed+Neemcake @ $400 \mathrm{~g} / \mathrm{sq} . \mathrm{m})$ showed the highest leaf length of $(71.83 \mathrm{~cm})$ and the minimum leaf length (60.33. $\mathrm{cm}$ ) was observed in $\mathrm{T}_{3}$ (Farmyard manure@ @000g/ sq m) followed by $\mathrm{T}_{2}$ (Vermicompost 2000g/ sq $\mathrm{m}$ ). The improvement in leaf length in tuberose with the application of vermicompost was also reported by Kabir et al., (2011). The improvement in leaf length with the application of seaweed was also noticed by Karthikeyan et al., (2014) in banana.

The treatment $\mathrm{T}_{5}$ (Seaweed+Poultry manure@ $1000 \mathrm{~g} / \mathrm{sq}$. m) has shown significantly highest leaf breadth of $3.09 \mathrm{~cm}$ and the minimum leaf breadth $(2.19 \mathrm{~cm})$ was observed in control followed by $\mathrm{T}_{2}$ (Vermicompost $2000 \mathrm{~g} / \mathrm{sqm}^{-1}$ ). The improvement in leaf breadth in tuberose with the application of vermicompost was also reported by Kabir et al., (2011). Karthikeyan et al., (2014) also noticed the improvement in leaf breadth in banana with the application of seaweed.
The given results revealed that organic manures and seaweed showed significant effect on growth of the plant. Among organic manures and their combination with seaweed, application of Seaweed+Neem cake@.400 g/ sq $\mathrm{m}$ showed the better results compared to others. This might be due to the fact that it improve the nutrient uptake by roots resulting in root system with improved water and nutrient efficiency and so it easily available for plants, and thus made it helps for the plants to enhanced plant growth and vigour. Seaweeds extracts also attributed to the presence of phyto-hormones such as auxins and cytokinns. Seaweed extracts also stimulated mineral nutrient uptake in plants with increased accumulation of both macro and micro-nutrients (Crouch et al., 1990).

\section{Flower parameters}

When different combinations of neem cake, poultry manure, vermicompost and neem cake were used with seaweed then the maximum spike length $(106.33 \mathrm{~cm})$ was recorded in treatment (Seaweed+Vermicompost@) $1500 \mathrm{~g} / \mathrm{sq} \mathrm{m}$ ) followed by treatment $\mathrm{T}_{5}$ (Seaweed+Poultry manure 1000g/ sq $\mathrm{m}$ ) (Table 2).

Highest spike weight (130.00 g) was found in treatment $\mathrm{T}_{8}$ (Seaweed +Neem cake@ $400 \mathrm{~g}$ / sq $\mathrm{m}$ ) followed by $\mathrm{T}_{6}$ (Seaweed + (Vermicompost @ 1500g/sq m) (128.00g).

The maximum rachis length $(33.33 \mathrm{~cm})$ was recorded in treatment $\mathrm{T}_{8}$ (Seaweed+ Neem cake @ $400 \mathrm{~g} / \mathrm{sq} / \mathrm{m}$ ) followed by treatment $\mathrm{T}_{6}$ (Seaweed+Vermicompost @) 1500g/sq. m) $(39 \mathrm{~cm})$.

Maximum diameter of $0.66 \mathrm{~cm}$ was recorded in $\mathrm{T}_{5}$ and (Seasweed+Poultry manure@) 1000 $\mathrm{g} / \mathrm{sq} \mathrm{m}$ and it is at par with $\mathrm{T}_{6}$ (Seaweed+Vermicompost @) 1500g/sq. m). 
Number of florets (40.33) and weight of 10 florets (18g) florets length (7.17) were recorded the maximum in treatment $\mathrm{T}_{6}$ (Seaweed+Vermicompost @ 1500g/sq. m).

The results of reproductive parameters revealed that application of organic manures showed significant differences on reproductive parameters. Spikes with good quality attributes like spike length, rachis length, spike girth and spike weight were produced which received seaweed along with other organic manures. These spikes had increased number of florets with increased length and diameter which in turn increased their fresh weight. This might be due to the fact that seaweed extracts improve nutrient uptake by roots resulting in root system with improved water and nutrient efficiency and improving soil structure and aeration. Seaweed extracts also contain hormones like cytokinin which linked with nutrient mobilization, thereby causing enhanced reproductive parameters. These plants had put forth good vegetative growth which enabled the plants to produce more photosynthates and supply to spikes for their development (Crouch et al., 1990) and (Padaganur et al., 2005). Similar improvement in reproductive attributes by the incorporation of vermicompost was reported by Patil (1999) in Jasmine and Sankar et al., (2015) in tuberose.

Table.1 Effects of organic manure on vegetative parameters of tuberose (Polianthes tuberosa) cv. Prajwal

\begin{tabular}{|c|c|c|c|c|}
\hline Treatments & $\begin{array}{c}\text { Plant Height } \\
(\mathbf{c m})\end{array}$ & $\begin{array}{c}\text { Number of } \\
\text { Leaves }\end{array}$ & $\begin{array}{c}\text { Leaf Length } \\
(\mathrm{cm})\end{array}$ & $\begin{array}{c}\text { Leaf Breadth } \\
(\mathrm{cm})\end{array}$ \\
\hline $\mathrm{T}_{0}$ Control (no organic manure) & 54.34 & 36.78 & 60.33 & 2.19 \\
\hline $\begin{array}{l}\mathrm{T}_{1} \text { Poultry manure@ } 1000 \mathrm{~g} / \mathrm{sq} \\
\mathrm{m}\end{array}$ & 60.44 & 48.11 & 69.23 & 2.95 \\
\hline $\begin{array}{l}\mathrm{T}_{2} \text { Vermicompost @1500g/sq } \\
\mathrm{m}\end{array}$ & 65.11 & 54.78 & 62.37 & 2.28 \\
\hline 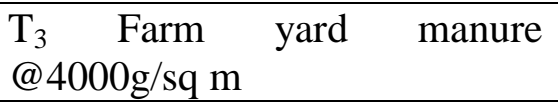 & 64.33 & 50.78 & 67.34 & 2.86 \\
\hline $\mathrm{T}_{4}$ Neem cake @ 400g/sq m & 68.34 & 50.67 & 70.33 & 2.96 \\
\hline $\begin{array}{l}\mathrm{T}_{5}(\text { Seaweed+ Poultry manure } \\
1000 \mathrm{~g} / \mathrm{sq} \mathrm{m})\end{array}$ & 65.55 & 55.44 & 67.82 & 3.09 \\
\hline $\begin{array}{l}\mathrm{T}_{6} \quad \text { (Seaweed+Vermicompost } \\
1500 \mathrm{~g} / \mathrm{sq} \mathrm{m})\end{array}$ & 68.92 & 62.78 & 70.63 & 3.08 \\
\hline $\begin{array}{l}\mathrm{T}_{7}(\text { Seaweed+Farmyard manure } \\
4000 \mathrm{~g} / \mathrm{sq} \mathrm{m})\end{array}$ & 67.33 & 52.44 & 68.40 & 3.00 \\
\hline $\begin{array}{l}\mathrm{T}_{8}(\text { Seaweed+Neem } \\
400 \mathrm{~g} / \mathrm{sq} \mathrm{m})\end{array}$ & 68.89 & 62.00 & 71.83 & 2.95 \\
\hline C.D. at $5 \%$ & 7.203 & 9.773 & 3.233 & 0.372 \\
\hline $\mathrm{SE}(\mathrm{m}) \pm$ & 2.382 & 3.232 & 1.069 & 0.123 \\
\hline
\end{tabular}


Table.2 Effects of organic manure on flowering parameters of tuberose (Polianthes tuberosa) cv.Prajwal

\begin{tabular}{|c|c|c|c|c|}
\hline Treatments & $\begin{array}{l}\text { Length of } \\
\text { Spike }(\mathrm{cm})\end{array}$ & $\begin{array}{l}\text { Weight of } \\
\text { Spike (g) }\end{array}$ & $\begin{array}{l}\text { Diameter of } \\
\text { Spike (cm) }\end{array}$ & $\begin{array}{l}\text { Rachis length } \\
\text { (cm) }\end{array}$ \\
\hline $\begin{array}{c}\mathrm{T}_{0} \text { Control(no organic } \\
\text { manure) }\end{array}$ & 93.33 & 98.33 & 0.42 & 19.00 \\
\hline $\begin{array}{c}\mathrm{T}_{1} \text { Poultry manure@ } \\
1000 \mathrm{~g} / \mathrm{sq} \mathrm{m}\end{array}$ & 101.83 & 113.00 & 0.52 & 25.67 \\
\hline $\begin{array}{c}\mathrm{T}_{2} \text { Vermicompost } \\
\text { @ } 1500 \mathrm{~g} / \mathrm{sq} \mathrm{m}\end{array}$ & 101.22 & 118.33 & 0.53 & 31.33 \\
\hline $\begin{array}{c}\mathrm{T}_{3} \text { Farm yard manure } \\
@ \text { @ } 4000 \mathrm{~g} / \mathrm{sq} \mathrm{m}\end{array}$ & 102.11 & 116.67 & 0.54 & 29.67 \\
\hline $\mathrm{T}_{4}$ Neem cake @ 400g/sq m & 102.33 & 115.17 & 0.53 & 32.00 \\
\hline $\begin{array}{l}\mathrm{T}_{5}(\text { Seaweed+ Poultry } \\
\text { manure } 1000 \mathrm{~g} / \mathrm{sq} \mathrm{m})\end{array}$ & 105.33 & 126.00 & 0.66 & 27.33 \\
\hline $\begin{array}{c}\mathrm{T}_{6} \\
\text { (Seaweed+Vermicompost } \\
1500 \mathrm{~g} / \mathrm{sq} \mathrm{m})\end{array}$ & 106.33 & 128.00 & 0.63 & 32.67 \\
\hline $\begin{array}{c}\mathrm{T}_{7}(\text { Seaweed+Farmyard } \\
\text { manure } 4000 \mathrm{~g} / \mathrm{sq} \mathrm{m})\end{array}$ & 104.22 & 126.00 & 0.65 & 31.33 \\
\hline $\begin{array}{c}\mathrm{T}_{8}(\text { Seaweed }+ \text { Neem cake } \\
400 \mathrm{~g} / \mathrm{sq} \mathrm{m})\end{array}$ & 102.99 & 130.00 & 0.66 & 33.33 \\
\hline C.D. at $5 \%$ & 4.294 & 16.582 & N/A & 4.945 \\
\hline $\mathrm{SE}(\mathrm{m}) \pm$ & 1.42 & 5.484 & 0.047 & 1.635 \\
\hline
\end{tabular}


Table.3 Effects of organic manures on flower quality and yield of tuberose (Polianthes tuberosa) cv.Prajwal

\begin{tabular}{|c|c|c|c|c|c|c|}
\hline Treatments & $\begin{array}{l}\text { No. of } \\
\text { Florets }\end{array}$ & $\begin{array}{l}\text { Weight } \\
\text { of } 10 \\
\text { Florets } \\
\text { (g) }\end{array}$ & $\begin{array}{l}\text { Floret } \\
\text { Length } \\
\text { (cm) }\end{array}$ & $\begin{array}{l}\text { Floret } \\
\text { Diameter } \\
(\mathbf{c m})\end{array}$ & $\begin{array}{c}\text { Vase life } \\
\text { (Days) }\end{array}$ & $\begin{array}{l}\text { Number } \\
\text { of spikes } \\
\text { per plot } \\
\text { per year }\end{array}$ \\
\hline $\begin{array}{c}\mathrm{T}_{0} \text { Control(no organic } \\
\text { manure) }\end{array}$ & 27.33 & 14.55 & 6.00 & 4.10 & 7.67 & 24.33 \\
\hline $\begin{array}{c}\mathrm{T}_{1} \text { Poultry manure@ } \\
1000 \mathrm{~g} / \mathrm{sq} \mathrm{m}\end{array}$ & 28.33 & 15.44 & 6.97 & 4.53 & 10.00 & 27.00 \\
\hline $\begin{array}{c}\mathrm{T}_{2} \text { Vermicompost } \\
@ 1500 \mathrm{~g} / \mathrm{sq} \mathrm{m}\end{array}$ & 34.00 & 16.16 & 6.93 & 5.60 & 8.34 & 27.33 \\
\hline $\begin{array}{c}\mathrm{T}_{3} \text { Farm yard manure } \\
@ 4000 \mathrm{~g} / \mathrm{sq} \mathrm{m}\end{array}$ & 28.33 & 15.00 & 6.50 & 5.30 & 9.34 & 26.33 \\
\hline $\begin{array}{c}\mathrm{T}_{4} \text { Neem cake @400g/sq } \\
\mathrm{m}\end{array}$ & 31.00 & 16.05 & 6.90 & 5.83 & 8.67 & 27.00 \\
\hline $\begin{array}{l}\mathrm{T}_{5}(\text { Seaweed+ Poultry } \\
\text { manure } 1000 \mathrm{~g} / \mathrm{sq} \mathrm{m})\end{array}$ & 37.33 & 17.33 & 6.77 & 5.60 & 11.34 & 30.33 \\
\hline $\begin{array}{c}\mathrm{T}_{6} \\
(\text { Seaweed }+ \text { Vermicompost } \\
1500 \mathrm{~g} / \mathrm{sq} \mathrm{m})\end{array}$ & 40.33 & 18.00 & 7.17 & 5.77 & 11.67 & 33.00 \\
\hline $\begin{array}{c}\mathrm{T}_{7}(\text { Seaweed+Farmyard } \\
\text { manure } 4000 \mathrm{~g} / \mathrm{sq} \mathrm{m})\end{array}$ & 35.67 & 16.76 & 6.67 & 5.23 & 11.00 & 30.67 \\
\hline $\begin{array}{c}\mathrm{T}_{8}(\text { Seaweed+Neem cake } \\
400 \mathrm{~g} / \mathrm{sq} \mathrm{m})\end{array}$ & 39.67 & 16.71 & 6.90 & 5.30 & 11.67 & 30.67 \\
\hline C.D. at $5 \%$ & 2.974 & 1.299 & 0.594 & 0.413 & 2.222 & 1.521 \\
\hline $\mathrm{SE}(\mathrm{m}) \pm$ & 0.984 & 0.430 & 0.196 & 0.137 & 0.735 & 0.503 \\
\hline
\end{tabular}

\section{Quality parameters}

\section{Vase life}

Among the different sole applications of organic manures, treatment $\mathrm{T}_{1}$ (poultry manure @ 1000g/sq m) showed the highest vase life of 10.00 days. When the sole application and combinations of organic manures with Seaweed were compared, then combination of treatment $\mathrm{T}_{8}$ (Seaweed+Neem cake @ 400g/sq m) and $\mathrm{T}_{6}$ (Seaweed + Vermicompost @2000g/sq m) showed the highest vase life of 11.67 day and the minimum field life (7.67 days) was observed in control.

The treatments with neem cake showed the best effect on quality parameters especially vase life. This may be due to more uptake of water by the cut spikes of treatments with neem cake and seaweed while they were in vase which may be of low microbial clogging as the neem cake has antimicrobial properties and also has property of protection from various microbes and improve water uptake 
by stem. The increase in vase life and water uptake by application of vermicompost was also noticed by Srivastava et al., (2007), Shankar et al., (2010) and Das et al., (2012).

\section{Yield parameters}

\section{Spike yield}

Spike yield was significantly varied among different treatments of organic manures. Significant improvement in the yield of spike can be observed upon application of organic manures in all treatments over control.

Among the different sole applications of organic manures, treatment $\mathrm{T}_{2}$ (Vermicompost 2000g/ sq $\mathrm{m}$ ) showed the highest number of spikes per sq $\mathrm{m}$ (27.33) (Table 3).

When the sole application and combinations of organic manures were compared, the combination of $\mathrm{T}_{6}$ (Seaweede + Vermicompost @ 2000g/ sq m) showed highest spike yield of 33.00 spikes per sq $\mathrm{m}$ per year and expected yield spikes per year. The minimum (24.67) was observed in control $\left(\mathrm{T}_{0}\right)$. The same results of high spike yield with vermicompost were also found by Das et al., (2012), and Tripathi et al., (2012).

The above results showed that seaweed application help to improve the efficiency of plant nutrients, as measured by either by improve nutrient uptake or reduced nutrient losses to the environment, or both or it acts as a soil amendment to help improve soil structure or functions and thus enhance yield. Similar increased yields due to incorporation of vermicompost were reported by Patel (1992), Kulkarni (1994) and Patil (1999), Singh (2000) and Marban et al., (2008). Dogra et al., (2009) and Sankari et al., (2015) also concluded that applications of seaweed extract significantly enhanced plant growth and yield.

\section{References}

Sankari, A, Anand, M and Arulmozhiyan, R. (2015). Effect of biostimulants on yield and post harvest quality of gladiolus cv. white prosperity The Asian Journal of Horticulture (0.1): 86-94: 621-631.

Crouch, I.J and Van Staden, J. (1992). Effects of seaweed concentrate on the establishment and yield of greenhouse tomato plants. J. Appl. Phycol. 4: 291296.

Das, P., Paswan, L., Choudhury, H., Das, J. and Saikia, P. (2012). Effect of inorganic, organic and biofertilizers on flower yield and flower quality of tuberose (Polianthes tuberosa L.). J. Crop Research, Hisar. 43(1/2/3): 11619.

Dogra, B.S., Mandradia, R.K. (2014). Effect of seaweed extract on growth and yield of onion. Int. J. Farm Sci. 2(1): 59-64.

Jeyrajan, R., Doraiswamy, S., Bhakaran, R., Jeyaraj, S. and Schmutterer. (1987). Effect of neem and other plant products in the management of plant diseases in India. Proc. $3^{\text {rd }}$ Int Neem Conf; Nairobi, Kenya, GTZ Press, Germany, pp. 635-644.

Kabir, A. K. M. R., Iman M. H., Mondal, M. M. A. and Chowdhury S. (2011). In Response of Tuberose to Integrated Nutrient Management, J. Environ. Sci. Natural Resources, 4(2): 55-59.

Khan W, Rayirath UP, Subramanian, S. (2009). Seaweed extracts as biostimulants of plant growth and development. Plant Growth Regul 28:386-399.

Karthikeyan, Munisamy and Shanmugam.(2014) Enhanced yield 
and quality in some banana varieties applied with commercially manufactured biostimulants aqua sap from sea plant Kappaphcus alvarezii.Journal of Agricultreal Science and Technology B 4:621-631.

Marban, L.; Giuffre, L.; Riat, M. and Romaniak, R. (2008). Comparison of conventional

fertilization and organic manures use for basil cultivation, J. Applied Hort., 10:8790.

Milton RF. (1964) Liquid seaweed as a fertilizer. Proc Int Seaweed Symp 4:428-431

Padaganur, V. G., Mokashi, A. N. and Patil, V.S. (2005). Flowering, Flower Quality and Yield of Tuberose (Polianthes tuberosa L.) as Influenced by Vermicompost, Farmyard Manure and Fertilizers, Karnataka J.Agric.Sci., 18 (3): 729-34.

Patil, S.R. (1999) Effect of organic, inorganic fertilizers and in situ vermiculture on growth and flower yield of jasmine. Ph.D. thesis, University of Agricultural Sciences, Dharwad.

Rajendra, P., Sharma, S. N., Singh, S., Prasad, M., Prasad, R., Kumar, V., Shotriya, G. C. and Kaore, S. V. (1990). Nitrogen management soil fertility and fertilizer use, Volume IV. Nutrient management and Supply System for Sustaining Agriculture in 1990's, 43: 41-51.

Srivastava, R., Vishen, V. S. and Chand, S. (2007). Effect of Azotobacter and organic manures on post harvest characteristics of tuberose (Polianthes tuberosa L.) cv. Double. Pantnagar Journal of Research, 5(1): 54-55.

Tripathi, S. K., Sunil malik, Singh, I. P., Dhyani, B. P., Vipin Kumar, Dhaka, S. S and Singh, J. P. (2012). Effect of integrated nutrient management in cut flower production of tuberose (Polianthes tuberosa L.) var. Suvasini. Annals of Horticulture, 5(1): 108-15.

\section{How to cite this article:}

Kahkashan Bano Karim, Nellipalli Vinod Kumar, B. Raghupati and Pal, A.K. 2017. Effect of Biostimulants on Growth and Floral Attributes of Tuberose (Polianthes tuberosa L.). cv. Prajwal. Int.J.Curr.Microbiol.App.Sci. 6(6): 2557-2564. doi: https://doi.org/10.20546/ijcmas.2017.606.304 